\title{
SACRED PANORAMAS: WALT WHITMAN AND NEW YORK CITY PARKS
}

\author{
JILL WACKER
}

IN MAY of 1842, the editorial staff of the New York Aurora claimed that "there is a man about our office so lazy that it takes two men to open his jaws when he speaks. If you kick him he's too idle to cry, for then he'd have to wipe his eyes." In August they reported that the same "pretty pup" once in their employ had become editor of a small, obscure daily. This pup was Walt Whitman, "whose indolence, incompetence, loaferism and blackguard habits" had forced the Aurora "to kick him out of office." That Whitman - the author of editorials such as "A Lazy Day"-was fired for, among other things, "loafing," is no surprise. "We felt dull and inactive all yesterday," wrote Whitman in one April 1842 editorial, "and sauntered forth to have a stroll down Broadway to the Battery." "Pottering" along, he arrives at "Gotham's glorious promenade":

We walked slowly and lazily back, enjoying the fresh air, and the delicious sunshine, and the intoxicating sweetness of the beauty of nature that appeared all around. (Brown and Rubin, 44)

I will try to show that in editorials like "A Lazy Day," Whitman's slacker pose enables him to use the panoramic narrative-a genre increasingly popular in mid-century fiction, journalism, and popular entertainment-to make prescriptions for open spaces in New York. Mastering this panoramic circulation, Whitman strolls the city and sketches the kind of place he would like to see it become as it responds to the changes that result from the massive immigration and breakneck expansion of mid-century. This journalist-flaneur, as his deadline rolls around, discovers the "chilling consciousness" of not having written a leader and "no recollection of having done anything in particular," yet is able, again and again, to mold his passerby's panoramic view of the burgeoning city into a treatise on the path of its development and welfare.

Throughout Whitman's career, from his editorials at the New York Aurora and Brooklyn Daily Eagle to poetic works such as Calamus and Drum-Taps, Whitman's investment in the development of city parks and public space lies at the very core of his construction of the American character, a character often at odds with popular nineteenth-century 
ideas of social responsibility, urban planning, and the restorative powers of nature. As early as the 1842 editorial "A Lazy Day," urban parks provide a medium for Whitman's exploration of democratic vistas and for the empowering possibilities of the unfettered, uninhibited gaze in a rapidly urbanizing city: "Is it not pleasant to be, once in a while, where your prospect is unintercepted by walls and stacks and of chimneys within a dozen arms' length?" (Brown and Rubin, 42). Some have argued that Whitman's writing about New York presages the advent of skyscrapers, emphasizing an upward movement of the eyes and recognizing height and verticality as the greatest of the modern city's achievements. ${ }^{2}$ I will argue that Whitman's agitations for public space change over time but that he ultimately champions the notion of allocating higher grounds for public use, allowing all city-dwellers the opportunity to experience the all-encompassing power of the panoramic.

Panoramas were executed in many media during the middle decades of the nineteenth century. In the years that Whitman wrote for New York's newspapers, the city was besieged by panoramas-in fiction, journalism, nonfiction, illustration, and performance-all aimed at middle-class audiences. Perhaps the most dramatic was the unfurling of Banvard's "Mississippi Panorama," painted on two giant scrolls said to cover three miles of canvas. More common were static panoramic 360degree views painted to encompass a geographically extended scene (usually an entire city) and panoramic narratives, strolling, circulating accounts of at once the diversity and prosperous unity of an entire region. These "bird's eye" idealizations of the city (more often than not taken from a church steeple) were offset by grittier, more sensational "mole's eye" views of the city in the popular press. The privileged, transcendent and unifying perspective of the "bird's eye" panorama often offered more information about middle-class ideas of the city than about the city itself. The ways in which Whitman spread the city around himself throughout his career are equally revealing. Circling the metropolis to create a uniquely American version of urban pastoral in his panoramic narratives, Whitman attempted to introduce the countryside into the city, as well as to break down distinctions between the two. ${ }^{3}$

The bulk of the pieces Whitman wrote for the New York Aurora in the 1840s are observations on city life, garnered from the many strolls and saunters he took outside of his newspaper office in Lower Manhattan. Wrapped up in Whitman's 1842 walks are arguments about the importance of democratizing open space, particularly spaces that allow inspirational vistas for the city's unenfranchised. Leaving the newspaper office, Whitman passes "the walks of the beautiful promenade which is the pride of Gotham," City Hall Park. Before long it will be summer:

And then the poor man and his little flock may enjoy a cheap treat (none the less precious because it is cheap) in passing a couple of hours there on Sunday. We should be better 
pleased were our city government to have more parks - more open places, where a man may look a few rods about him, and his gaze not be intercepted by brick walls, and chimneys, and fences. (Brown and Rubin, 31)

Whitman's editorials, although couched in the reformist rhetoric which would have been so familiar to his middle-class readers, rarely condescend to their subject. Instead, Whitman sides with urban children against those who inflict rules of conduct on them in places like parks. The 1842 editorial "A Lazy Day" also includes a lesson about the democratizing force of public leisure grounds, as Whitman strolls into contact with a group of boys spread out on the park walk playing marbles. The boys anticipate Whitman's approach and prepare to clear a path, but Whitman preempts them, turning off the path so as not to disturb their game. In the end, they are all "gentlemen," sharing democratic space. In a later editorial, "Playing in the Park," Whitman critiques the administration of the park, defending the "poor ragged little devils, with plenty of dirt, and plenty of the signs of poverty about them," who come to the Battery to run, trundle hoops and play marbles and are often "cuffed" and turned out by the park patrol:

Because these children are poor, dirty, and ragged, that is no reason why they should be whipped in this manner, and prevented from pursuing their little amusements. On the Battery, and in other public grounds, any quantity of the offspring of the rich and fashionable may be daily seen playing and no objection made. Such conduct may hardly have the effect of teaching the proper moral to young republicans. (Brown and Rubin, 47)

The urchins he defends have no need for reform: "they offend nobody, they interfere with nobody." It is the children of the upper classes, those who will grow into the reformers who "inveigh against the filth and disease and neglect of Hygiene of the masses" and who need to learn from parks the lessons of calm and accepting nature. ${ }^{4}$

These early promenades also foreshadow the hybrid catalogues of Whitman's later poetry, in miniature:

Many of both sexes, fashionable ladies, well dressed men, a sprinkling of loafers, and rather more than the usual quantity of "people from the country," were out upon the pave. We cast listless glances, at the mingled mass. At everything that was to be seen around-and so sauntered down to the Castle Garden entrance . . . having spent an hour as pleasantly as any man could wish. (Brown and Rubin, 49)

The massive, all-inclusive lists of the later poetry represent a kind of expanded version of faces seen on the Battery, faces which, incidentally, deconstruct notions of the city. Even this limited panoramic mixes urban and rural, defusing and undermining any opposition of city and country, ending with an endorsement of a heterogeneous city life that includes a smattering of country life in its celebration of the ideal. 
Whitman's investment in constructing a city life with the aesthetic appeal of a country life is a direct response to the hectic growth of New York and Brooklyn in the late 1840s and 1850s. Working as a journalist and editor, Whitman was closely involved with the changing life of the city. He understood the social and political consequences of the radical transformations of its character and reacted to the many unresolved conflicts being played out among its citizens. Contrasts between wealth and poverty intensified, as dizzying technological, economic and social changes rapidly dismantled the old order. New York's older merchant community was disrupted by the rapid expansion of business, introducing a new capitalist order that was increasingly complex, impersonal, and competitive. Whitman had to make choices about the world he was to represent. The pace of life in the streets was mesmerizing, as was the city's growing awareness of itself as a historic and human invention, the yoking of commerce and manufacture to a maritime landscape in what Whitman hoped was a democracy of the sublime. Whitman was a notable exception to the general nineteenth-century rule that American intellectuals were both hostile to and critical of the American city. ${ }^{5}$ The difference between Whitman and most nineteenth-century commentators is that Whitman was a journalist. Year after year, he was in the trenches of urban newspaper reporting, explaining, justifying, exhorting, admonishing, defining, and redefining the essence of a chaotic and sprawling city and its people, imposing order and shape on them with his words.

By September 1845, when Whitman moved back to Brooklyn from Manhattan, he had worked for about ten different papers, including the Tattler, Sunday Times, Statesman, Plebeian, Sun, Democrat, and New Mirror. As editor of the Brooklyn Daily Eagle (1846-48), he occupied an office at the lower end of Brooklyn's bustling main street, Fulton, from which he had a good view of the Fulton ferry terminal. Year after year, Whitman was engaged in the act of writing the city into existence, and the city he wrote was the same one he saw while sauntering through City Hall Park or looking down Fulton Street. New York was a newspaperreading city, and its citizens read newspapers to a degree unprecedented in other societies. ${ }^{6}$ For Whitman, newspapers continued to hold the power to influence popular institutions to democratic ends and to create new forms of expression and protest. Journalists described the city's problems and then led the way in proposing remedies for them. While he called for inspired poets in Democratic Vistas, Whitman also perceived journalism as "a source of promises, perhaps fulfillments, of highest earnestness, reality and life."7 Newspapers also did important work at a national level, using "panoramic" coverage to hold together a nation ready at any instance to fly apart or simply to disintegrate into its disparate and warring elements. Torrents of words, describing, explain- 
ing, and reconciling Americans to each other, to the United States of America, and to the newly important cities, worked at making the nation a cohesive whole.

In Whitman's time, the main anxiety that this torrent of words had to address was the course of rapid change, the replacement not only of systems and values, but of the urban landscape itself. New buildings went up on the rubble of the old, stores replaced residences, the characters of streets and entire neighborhoods changed overnight. Sometimes a deep-down, although intermittent, conservatism that equates change with evil emerges in Whitman's journalism. Construction on Delancey Street unearths an old burial ground, and Whitman's outraged description of moldering bones is positively ghoulish. ${ }^{8}$ Everywhere he looked, stability, tradition, and piety were being erodedexcept in the open spaces which remained in the metropolis, the open spaces that Whitman hoped would become parks.

When, in the 1860 poem "No Labor-Saving Machine," Whitman bemoaned the poet's failure to invent a labor-saving machine or leave behind a "wealthy bequest to found a hospital or a library," he seemed to have forgotten the decades of advocacy engendered in his various editorials. If indeed he did fail to make money or machinery, he did not fail in his efforts to establish a legacy of sacred places for Americans. While editor of the Brooklyn Daily Eagle in 1846, he campaigned against the leveling and development of Fort Greene, a revolutionary war battlement, in favor of its establishment as a park or memorial. Cautiously anti-capitalist in its rhetoric, the editorial "Fort Greene Park, Brooklyn," reflects Whitman's own vision of the relationship between recreation, open space, and America's invention of itself. For Whitman, a large part of national identity springs from people's relationship with the land. ${ }^{9}$ It was inevitable, therefore, that Whitman would turn to the preservation of his beloved Brooklyn landscape in his battle against change. "Is the Dollar-god so ruthless that he grudges a few poor acres, to the service of health, of refinement, of religion? Is nothing to be thought of on earth but cash?" he asked. ${ }^{10}$ Once again, he saunters the turf of everyman and offers his readers an idealized human panorama from atop Brooklyn's Fort Greene:

A thousand people, hundreds of them children, were there. In the sweet marine breezes, those young creatures gambolled over the grass. Women and men walked to and fro. (Rodgers and Black, 48)

At Fort Greene, elevation is the great leveler. In Whitman's vision, the projected park is not gender-identified. Women and men share the grounds of recreation (often with children) and in doing so share the same space-an uncommon situation in the mid-nineteenth century. The "masses," said Whitman, had fixed upon Fort Greene "as a Place 
of the Ideal." It is no coincidence that the stretch of ground the masses fix on has a view of six counties. This "ideal" is a panoramic view that is nature's equivalent of the popular middle-class entertainment, an expansive hybrid landscape. In visiting the park, Brooklynites not only experience the benefits of fresh air, but the ability to survey all of New York City with a possessive eye:

At their feet lay stretched out the hot shingled roofs of the houses of Brooklyn. Around on every side could be viewed a surprisingly splendid scene. You counted six counties. On either side was a sweep of noble river, with the metropolis like a map beyond. (Rodgers and Black, 49)

Moments like these show Whitman at odds with the popular rhetoric in support of public parks, perhaps even at odds with what was popularly understood in the term "park." Throughout the nineteenth century, dictionaries offered conceptions of the word "park" only as an "enclosed" piece of ground for public recreation or amusement. ${ }^{11}$ Rather than enclosure or containment, Whitman offers park visitors the vicarious pleasures of a limitless and empowered vista. Sure that he has communicated the soothing effects of the democratizing vistas afforded by high ground, Whitman returns to the framework of popular discourse, supporting the notion that parks are didactic, recuperative entities designed and provided by elites for the assimilation of rogue elements:

And it was curious to observe how in that crowd the genializing influence of the scene infused itself, and destroyed all those objectionable traits so often met in the city crowds. These were mild, subdued, and graceful. Is this the place for desecration? (Rodgers and Black, 50)

The "genializing influence of the scene" Whitman ascribes to this democratic vista carries with it the notion of property. As the nineteenth century wore on, "view" came to mean more than an opinion or a vista. Panoramic views were beginning to be understood as inalienable rights. Worcester's Dictionary of 1882 cites legal precedents in the property value of view and offers as an example of popular usage the idea that a neighbor cannot build to obstruct the "view" of another. ${ }^{12}$ For Whitman, views were the inalienable right of the average city-dweller, and his urgings for the creation of public parks always point to the higher ground as a spot from which one who owned little could behold the workings of the world's greatest capitalist city and derive pleasure from it. Whitman wrote disapprovingly of the American obsession with utilitarian ends. He hoped the creation of parks would encourage a greater regard for beauty and for the leisure to enjoy it. In other words, Fort Greene Park seemed to offer a cultural check on aggressive fantasies of exploiting America's resources to the fullest extent possible: 
We respect and admire trade and commerce. They are noble agents (in their proper and better action), for elevating man, breaking down local prejudices, tightening the common bonds of brotherhood, and clearing the strength of thought. But scorn the prostitution of their name, to achieve the pettiest ends. (Rodgers and Black, 50)

Later, Whitman would look up to the heights of Fort Greene from Brooklyn Ferry, wondering "whether the new Washington Park . . . would not be quite as noble a promenade, even without the water-front: it would have a far more magnificent water-view, you know. . .."13 Even early on, Whitman pressed the limits of most journalists' cautiously anti-capitalist rhetoric. Once he triumphed over less enthusiastic Brooklyn editors in championing the preservation of the park, he began to suggest (playfully) the elimination of the commercial waterfront altogether, in order to improve the "water-view."

In July 1846, Whitman continued his advocacy of Fort Greene as a spot for public recreation, cagily reporting the politesse of Fourth of July celebrations on the hill: "Imagine the high summit of the old Fort, with ceaseless but mild sea breezes dallying around it; not a taint of streets or close human dwellings; but the most fresh odor of dewsprinkled grass, instead" (Rodgers and Black, 118). Hung "between heaven and earth," on the borders of a "seventy-thousand-souled city," Fort Greene Park provided a stark contrast to urban ills. At a time when the most urgent question facing the nation was how to check the accelerating slide into chaos so evident in the cities, and, once that was done, how to transform the city from a hell to a heaven, Whitman once again offers a redemptive vision of men and women, young and old "reclined upon the grass, there, in the moonlight: and one third the great gathering were women, and more than half the rest, children . . ." (Rodgers and Black, 120). If the gentility and domesticity of the gathering are not gratifying enough to win people to its side, there is another comforting vista for the reader, prepared to relieve any middle-class anxieties about crowd control in New York's heterogeneous, uncontrolled gathering places:

It was soothing to see such a huge mass of humanity so penetrated with ethereal beauty over and around them! In cities, what a tumultuous thing is a mob! How coarse and clattering! So were not the thousands last night on Fort Greene. Quieted, refined by the poetic repose of Nature, they "behaved" after a method that would not have been unseemly in the parlors of nobles. (Rodgers and Black, 119)

One of the reasons Whitman was so attached to Fort Greene was its history as a revolutionary war battleground. In 1847, Whitman called for the erection of a monument to the soldiers who died, "during the days that tried men's souls, in the British hulks, at the Wallabout" (Rodgers and Black, 51). The creation of Fort Greene Park was authorized by the legislature in 1847, but the monument, which Whitman 
argued was not a sectional claim because "the prisoners were from all parts of the Union, and their graves should be cherished as national graves," was not constructed until 1908 (Rodgers and Black, 52). In 1858, Whitman returned again to the theme of Fort Greene, with the construction of the new Brooklyn arsenal. Many of Whitman's newspaper pieces are a sort of cultural geography, outlining the landscape with cultural and historical value for local readers. Fort Greene is not just a park, it is literally the fortification which secured the safety of American troops against the British: "Indeed some of the highest walks of the present Park are literally the ground thrown up by the patriotic hands of the men and boy volunteers" (Holloway and Schwarz, 153). Whitman marks Fort Greene Park as a site of the average man's heroism, reflecting changing attitudes about national heroes. The American public no longer thought in terms of the generals who had commanded the two armies as the only individuals deserving to be honored. There were tens of thousands, many of them volunteers, who had fought and died and who Whitman believed deserved a collective monument. In this case, the elevated landscape of Fort Greene offers a historical rather than contemporary unification, a closing of old wounds in anticipation of future traumas.

Fort Greene eventually became part of the material for "The Centenarian's Story," written in 1861. In this poem, a volunteer of 1861-2 assists a veteran of the Revolutionary War in a visit to Fort Greene, "walking then this hilltop, this same ground." 14 Whitman reveals the complex roots of his battle for historic preservation:

Aye, this is the ground,

The years recede, pavements and stately houses disappear, Rude forts appear again, the old hoop'd guns are mounted, I see the lines of rais'd earth stretching from river to bay, I mark the vista of waters, I mark the uplands and slopes;

Here we lay encamp'd, it was this time in summer also. (Whitman, 431)

The nationalism of this poem about Fort Greene is a conflicted nationalism. The poem celebrates a past history books do not describe: a vernacular past with no dates or names, simply a sense of the way things used to be, a history of everyday experience. Although General Washington features in this poem, its basic focus is on the average soldier, ensconced in raised earth, camping in pre-urban Brooklyn and surveying the land. There is also an echo of the necessity for reportage in recording this historic, panoramic gaze on the landscape, an echo of the editorials of ten and more years earlier in the lines "I must copy the story, and send it eastward and westward, / I must preserve that look as it beam'd on you rivers of Brooklyn" (Whitman, 434). The panoramic gaze Whitman allows these foot soldiers is the constitutive element of a 
history both descriptive and anticipatory.

The poem serves as a sort of foreground for the urbanizing Brooklyn of the 1860s and attempts to locate national origins not only in a specific event, but in a golden age when culture was at one with its environment. As the storm clouds of the Civil War loomed on the horizon, Whitman, exhausted by questions not only of national origin but of national futurity, offered a vision of a slow and sure national evolution underfoot in Brooklyn, beginning with the very first settlements (or battlements) and moving on to celebrate its legendary, halfforgotten origins in the landscape:

\footnotetext{
Ah, hills and slopes of Brooklyn! I perceive you are more valuable than your owners

supposed;

In the midst of you stands an encampment very old,

Stands forever the camp of that dead brigade. (Whitman, 435)
}

Ruins and national sites of pilgrimage had become a necessity in Whitman's vision of America. Neither George Washington nor the "landscapes projected masculine, full-sized and golden" of the 1855 Leaves of Grass can offer the specific attachment of these Brooklyn battlements. Whitman's ruins are reminders of the private vernacular past, a history less the record of significant events and people than of the minutiae of a bygone domesticity. In poems like "The Centenarian's Story," echoes from the remote past suddenly become present and actual, perhaps because the past is more palatable then the present. The prescriptive recession of Whitman's poem and editorials about Fort Greene warrant comparison to the dedication of another site. In 1863, Abraham Lincoln delivered the address at Gettysburg, the ostensible purpose of which was to dedicate a small graveyard where the remains of Union soldiers were buried. Lincoln's speech, much like Whitman's work, can be read as a description of what a monument means. Lincoln's Gettysburg address endows the monument as a guide to the future, a reminder of the covenant of a bygone time, earth containing ordinary men rather than heroes. Just as it confers a kind of immortality on the dead, it is designed to determine actions in the years to come.

The Gettysburg gravesite soon became a popular tourist attraction, a pilgrimage site that was (and is) part of a national mythology. Part of the Gettysburg experience has long been ascending to one of two heights to take in a panoramic view of the battlefield. In more than one way, this was in keeping with previously established patterns of nineteenthcentury tourism. Whether natural or man-made, tourist attractions stood apart from ordinary reality. They replicated in significant ways the functions of sacred places in archaic societies. The strong religious tradition of many Americans predisposed them to construct the symbolic landscape of their own country in a similar fashion, often with 
millenial expectations. As J.B. Jackson has noted, the "religious meaning" of national monuments "was broad enough to appeal to people of any persuasion. In a pluralistic society they provided points of mythic and national unity."15 Gettysburg was in keeping, too, with a nineteenth-century tradition of tourism at cemeteries.

Rural cemeteries just outside city limits like Greenwood Cemetery in Brooklyn provided pre-park settings for bourgeois city dwellers to relieve the anxiety they felt about the rapid physical and social changes happening in American cities in the nineteenth century. Cemeteries were places where time stood still. Urbanites frequented places like Greenwood for the same reason they moved to the suburbs: to escape the unpleasant effects of industrialization. In June 1846, Whitman wrote a piece about a visit to Greenwood for the Brooklyn Daily Eagle, noting that Greenwood was a place "our readers probably know," and using the occasion of the cemetery visit to muse on Brooklyn's expansion: "the sentiment that always fills us about as much as anything else, on going this road, is the rapidity with which Brooklyn has spread itself, during the past twelve years ..." (Rodgers and Black, 107). Much of the essay reads like a promotional tourist brochure, encouraging a visit to the "Beautiful Place of Graves" as an antidote to civilization for "the whole mass of our population-the delver for money, the idler, the votary of fashion, the ambitious man." Whitman admits walking off the beaten track at Greenwood, into "the more retired groves," including those assigned to a little girl, "Rosa," and "Do-hum-me," young wife of the chief of the Iowa tribe, "who died in this neighborhood two or three years ago." Whitman can use Greenwood to mull over local as well as national questions because of its elevation. From the cemetery's upper reaches, the view outstrips that of Fort Greene.

New York's Central Park itself emerged from the garden cemetery vogue of the 1840s. Even some of the most ardent admirers of the rural cemeteries felt that their use as pleasure grounds was inappropriate. Their popularity was proof of the need for urban parks of similar scale. Like their counterparts in tenement reform, park advocates from the first saw an important moral dimension to their efforts. The mayor of New York, calling for a park appropriation in 1851, argued that such a retreat in the city would provide a morally preferable alternative for the thousands who were spending their Sundays "among the idle and dissolute, in porter-houses or in places more objectionable." 16 In 1856, New York City acquired 840 acres in upper Manhattan for park purposes and announced a design competition. The winners were Frederick Law Olmsted and Calvert Vaux; the rationale for their plan called for the visitor's "complete immersion" in the scenery of the park, an experience they proposed to create by "planting out" the city with a green barrier of trees and shrubs along the perimeter of the park. The 
border of trees was intended by Olmsted to mark a change in the nature of time. Within the sacred space of the park, time would no longer be experienced as pressing. The hurry of the city would be replaced by a leisured, meditative state of mind. Olmsted's concept of the urban park in both its spatial and temporal dimensions suggests a nostalgia for an age in which the problems of the city and of a commercial, capitalist society did not exist. As an antidote to the ills of the city, the large public park would provide fresh air, open space, and tranquility, and, since situated at the very center of the city rather than in the suburbs, it had the advantage over the rural cemetery of being readily accessible. It would be possible to step out of the busy street directly into the soothing atmosphere of the park. Soon afterwards, Henry Ward Beecher welcomed Brooklyn's Prospect Park, where a berm of heavily planted earth just inside the walls effectively blocked out any view of the city, as a distinct moral asset to the city. ${ }^{17}$ "The divine element of beauty in nature," he felt, would inspire the poor to "gentle thoughts and grateful silence." 18

Parks that screen out the city stand in direct contrast to the sorts of parks Whitman favored, parks with vistas of "six counties," the river, and commerce. In Specimen Days, Whitman complained of Central Park's lack of vistas and chose to sit near a policeman just outside the park, with a view up and down Ninetieth Street (Whitman, 844). Olmsted's plan is reminiscent, however, of the sort of quiescent reform witnessed in Whitman's earlier editorials about the crowds at Fort Greene. Here, too, is a park that plans on teaching "courtesy, selfcontrol and temperance" through doctored nature, on taming the unruly passions of the dangerous classes, those who were perceived as a threat in numbers, such as men loitering on the streets and immigrants.

Olmsted's definition of the park was based on the idea that the land was an example of natural scenery which acted "in a directly remedial way to enable men to better resist the harmful influences of town life and to recover what they lose from them." ${ }^{19}$ For the most part, the city park was for Olmsted aesthetic, a three-dimensional landscape painting. Olmsted reduced the bric-a-brac beloved by the earlier landscape architects and cemetery tourists: ruins, historical allusions, rustic shelters and tombs. Instead, Olmsted emphasized the importance of counteraction, of the park as an antidote to urban life, the visual inverse of the unrelenting grid of city streets and ungiving architecture. The remedy for the frequently mentioned "exhausted townsman" remained purely an aesthetic experience: block out the city, let the gaze fall on a carefully reconstructed nature, and emerge refreshed.

On the eve of the Civil War, when Central Park was nearing completion, more public discussion arose about its purpose. No longer mere open space designed to stave off encroaching urbanization, the 
park was assigned a more didactic mission. The democratic quality of the park was given high value. All agreed that the park was intended for the enjoyment of all walks of life. Some thought of the park as a means of inculcating traditional cultural values and acceptable modes of public behavior through an edifying (if forced) contact with art. An arboretum and botanical garden were included in the original plans for Central Park, and countless other cultural installations were suggested during the park's first decades. Reformers cited the response of the public in their quest to make the park more didactic. Observers were gratified to see that visitors of all classes rose to the occasion of a park visit. "It has been observed," said one writer in 1869, "that rude, noisy fellows, after entering the more advanced or finished parts of the Park, become hushed, moderate, and careful" (Jackson, American Space, 213). It is difficult to imagine what else observers expected visitors to do, given that the park made almost no provision for sports or similar entertainments. The limited playground space, for children only, was open only to those children who could present a certificate "from his or her teacher of punctual attendance at school, and of good character." Although Whitman maintained that a good game of marbles made the most ragged urchin a gentleman, it is difficult to imagine his Battery gang being granted admission to the playground of Fifth Avenue. After the Civil War, two distinct and conflicting definitions of the park continued to clash. The upper-class definition, with its emphasis on cultural enlightenment and greater refinement of manners, continued to advocate the redefinition of Central Park as a sort of "theater of memory" studded with monuments, statuary and cultural institutions. On the other hand, working-class interests voiced their support of a park devoted to fun and games. In the end, neither got the upper hand in Central Park.

Ten years after the establishment of Washington Park at Fort Greene, and around the same time that this debate raged over Central Park, Whitman wrote an editorial which indicated that the Brooklyn park did not live up to his expectations. His disappointment had in large part to do with poor landscape architecture. Perhaps he was calling for the attention of Olmsted when he wrote:

For grandeur of situation, we doubt if there is a finer public ground in the world . . . The views from some of its elevated points sweep over a wide distance, comprehending city and country, houses, shipping, and steamers, sea and land, hill and hollow. There has not been much judgment exercised in laying out the ground, however. The trees especially have never been well-chosen nor well-placed. In some spots where they are in the way, they have been multiplied and there is a little too much military regularity in their arrangement. There should have been a fuller selection of American native trees. ... . (Holloway and Schwarz, 141)

Ever the Brooklyn partisan, in 1858 Whitman urged the creation of yet another panoramic Brooklyn park: 
. . . a Park on the heights, over Montague ferry! A small portion of that most superb of grounds is yet vacant on the heights - the best part of it - commanding a wide view of as noble a panorama as there is anywhere in the world-we mean the bays, shores, rivers, and island of New York, with all their moving life. We have heard of a move to secure this ground for a public promenade. If done at all, it must be done soon; for a season or two more will put it out of reach. (Holloway and Schwarz, 141-142)

Whitman's use of the term "panorama" no longer refers to specific middle-class entertainment but instead to a new way of perceiving the city as a cohesive whole. To promenade and experience this panorama is a pleasant entertainment; it is also a political experience of completion, of the democratization of the gaze of the beholder. Even as its tone is more overtly anti-commerce and preservationist than that of earlier editorials, this piece advocates not sublime nature set aside for the public good, but the preservation of vistas into sublime commerce, the constant motion of New York's commercial harbor.

I would not suggest that "A Song of the Rolling Earth," which Whitman wrote in 1856, anticipated these issues, but it does seem to address the problem of democratizing space in a capitalist economy and a city where moral, social, and aesthetic reform remained in the control of the elite. In this stanza, Whitman holds out hope for all-inclusive design:

I swear to you the architects shall appear without fail,

I swear to you they will understand you and justify you,

The greatest among them shall be he who best knows you, and encloses all and is faithful to all,

$\mathrm{He}$ and the rest shall not forget you, they shall perceive that you are not an iota less than they,

You shall be fully glorified in them. (Whitman, 386)

Whitman continued to comment on parks when he returned to New York after the Civil War, but by then his approach to the issue of democratized urban space was more pessimistic than hopeful. Central Park's battle to strike a balance among the myriad functional demands for space remained inconclusive, as the elite and the popular battled for pre-eminence:

I hear it was charged against me that I sought to destroy institutions.

But really I am neither for nor against institutions,

(What indeed have I in common with them? or what with the destruction of them?)

(Whitman, 281)

When Whitman wrote in Calamus that he was "neither for nor against institutions," he was not talking about cultural institutions; when he championed parks, he sought himself to establish cultural institutions. In Democratic Vistas he wrote of the effect that "the litera- 
ture, songs, esthetics, \&c., of a country" had in furnishing "the materials and suggestions of personality for the women and men of that country" (Whitman, 958-959). Much of Whitman's later writing is about the raw materials that make up American national character and national culture, "the main thing being the average, the bodily, the concrete, the democratic, the popular, on which all the superstructures of the future are to permanently rest" (Whitman, 994). His later work embodies the tensions between the life of the city and nation and the concurrent desire to retreat into nature similar to those of his early journalistic work. This tension between the pull toward solitude and stasis in nature and the opposite pull toward involvement in society informs both Specimen Days and Democratic Vistas. Specimen Days, in fact, records three distinct stages in Whitman's involvement in American society: the war memoranda record a period of intense social interaction, the nature notes record Whitman's withdrawal from society to the seclusion of Timber Creek in New Jersey and the poet's selfprescribed health cures, and the final notes record Whitman's reinvolvement in society, particularly in the world of New York and even of New York's parks.

What is interesting about Whitman's re-entry is his resumption not only of urban activity, but of concern with the same social problems he addressed as a journalist in the 1840s. In particular, Whitman's New York excursions recall a familiar formula for celebrating and at the same time rejecting the commercial "superstructure" which creates the city. Opening Democratic Vistas in 1870, Whitman once again celebrates the panoramic manifestations of commercial prosperity and bustling activity in New York:

After an absence, I am now again (September 1870) in New York city and Brooklyn, on a few weeks' vacation. The splendor, picturesqueness, and oceanic amplitude and rush of these great cities . . . the endless ships, the tumultuous streets, Broadway . . . the rich shops, the wharves, the great Central Park, and the Brooklyn Park of Hills, (as I wander among them this beautiful fall weather, musing, watching, absorbing) . . give me . . . a continued exaltation and absolute fulfillment. . . . (938)

Continuing with the same circulating mix of prospect and promenade, he is able to find that "not Nature alone is great in her fields of freedom and the open air, in her storms, the shows of night and day, the mountains, forests, seas-but in the artificial, the work of man too is equally great" (Whitman, 939). Whitman takes joy in contrasts, especially the contrasts created by urban parks, the artificial/natural creations of advocates like Whitman himself. These writings are, finally, an expression of enthusiasm for American commercial prosperity, society as a fitting accompaniment to nature. 
In "A Fine Afternoon, 4 to 6," written in 1879, however, Whitman uses a visit to Central Park as a vehicle for a scathing class critique. Repeating the sort of hortatory description of diversity and prosperity that characterizes descriptions of New York in Democratic Vistas, this Specimen Days piece first lauds the parade of "Ten thousand vehicles careening through the Park" as representatives of "the full oceanic tides of New York's wealth and gentility," suggesting that the show is in complement with nature, "on a grand scale, full of action and color in the beauty of the day, under the clear sun and moderate breeze." Yet within the scope of this short diary-like entry, forty years after he celebrated the spectacle of the promenade in pieces like "A Lazy Day," New York parks fail Whitman. The urban vista no longer offers light or redemption, only a homogeneous sample of the city's least deserving park visitors, those of great wealth, encased in coaches that provide only foreshortened vistas and myopic views:

Through the windows of two or three of the richest carriages I saw faces almost corpse-like, so ashy and listless. Indeed the whole affair exhibited less of sterling America, either in spirit or countenance, than I had counted on from such a select mass-spectacle. I suppose, as a proof of limitless wealth, leisure and the aforesaid "gentility," it was tremendous. Yet what I saw those hours . . . confirms a thought that haunts me every additional glimpse I get of our top-loftical general or rather exceptional phase of wealth and fashion in this country-namely, that they are ill at ease, much too conscious, cased in too many cerements, and far from happy - that there is nothing in them which we who are poor and plain need at all envy, and that instead of the perennial smell of the grass and woods and shores, their typical redolence is of soaps and essences, very rare may be, but suggesting the barber shop-something that turns stale and musty in a few hours anyhow. (Whitman, 844-845)

Central Park has failed in its efforts to democratize the landscape. By now the divisions between working-class urbanites and the "gentility" are great enough for Whitman to unleash his criticism of the unnatural, decaying, and indeed "corpse-like" panorama offered by the fin-desiècle park. Finally, Whitman is able to let his landscape and the park's spectacle of humanity admit that his city has unsettled problems and tensions. The empowering processional panorama Whitman advocated in writing about parks can only be experienced on foot, and when strollers and lookers fail to materialize, there is little hope for the democratization of open space.

In Democratic Vistas, Whitman wrote of air and light, allowing for the possibility of an outdoor urban life uncorrupted by high society: "Ever the most precious in the common. Ever the fresh breeze of field, or hill, or lake, is more than any palpitation of fans, though of ivory, and redolent with perfume; and the air is more than the costliest perfumes" (Whitman, 969). A later visit to the park urges Whitman to record the alarming evidence of an emerging and all-corrupting Ameri- 
can aristocracy, borne out once again in carriage traffic:

And on the large proportion of these vehicles, on panels or horse-trappings, were conspicuously borne heraldic family crests. (Can this really be true?) In wish and willingness (and if that were so, what matters about the reality?) titles of nobility, with a court and spheres fit for the capitalists, the highly educated, and the carriage-riding classes - to fence them off from "the common people"-were the heart's desire of the "good society" of our great cities. . . . (Whitman, 1176)

An afternoon of closely observed social critique falls under the same guise of loafing self-discovery as these lines from 1855:

Swift wind! Space! My Soul! Now I know it is true what I guessed at; What I guessed when I loafed on the grass. ... (Whitman, 59)

What did Whitman guess as he loafed on the grass? That the rise of capitalism in New York would corrupt its open spaces? That the open spaces, the blades of grass, which remained would be the only ones able to tell the true story of the city and the nation? "The Battery-its past associations - what tales those old trees and walks and sea-walls could tell!" (Whitman, 705). I would like to suggest that one of the things that Whitman discovered as he loafed on the grass was the inherent connection between democracy and fresh air. The final essay of Specimen Days, titled "Nature and Democracy-Morality," states unequivocally that for "American democracy, in its myriad possibilities," to exist, it must be "fibred, vitalized, by regular contact with out-door life and growths" (Whitman, 925). Whitman goes on to claim that this mixture of sophisticated and elemental life is the sensibility which underlies "the whole politics, sanity, religion and art of the New World" (926). What better way to enact this contract than through the establishment of urban parks in a land with no common racial origin and no common history? Flooded by immigrants in the nineteenth century, New York was a patchwork of peoples. With no shared religion, no grounding in a common language, few shared customs, the nation was in need of accessible, visible icons of both freedom and unity. In writing about the leveling effect of elevated parks and urging their construction, Whitman encapsulated and solved these needs at a local level, timelessly-with lookouts, vistas into the sublime.

\section{University of Pennsylvania}

\section{NOTES}

1 Charles H. Brown and Joseph Jay Rubin, eds. Walt Whitman of the New York Aurora: Editor At Twenty-Two (State College, Pa.: Bald Eagle Press, 1950), 13. All further references will be to this edition and will be documented in the text. 
2 Graham Clarke, “A 'Sublime and Atrocious Spectacle': New York and the Iconography of Manhattan Island," in The American City: Literary and Cultural Perspectives (New York: St. Martin's, 1988). Clarke explains Whitman's "upward" gaze as a sort of prophesy of Manhattan skyscrapers: "These towers have supplanted other icons of earlier periods but, as the tallest buildings in Manhattan, they also fulfill Whitman's sense of the city as a vertical growth" (58).

3 Walter Benjamin writes in "Daguerre, or the Panoramas" that in the panorama, "the city dilates to become landscape." Reflections: Essays, Aphorisms, Autobiographical Writings, translated by Edmund Jephcott, edited by Peter Demetz (New York: Harcourt, Brace, Jovanovich, 1978), 150. Many have written about the panoramic perspective so central to Whitman's work. Hans Bergmann's "Panoramas of New York, 1845-1860" (Prospects 10 [1985], 119-137), a history of the city's constitutive images, is perhaps the most useful investigation of the panoramic paradigm in literature. Charles Zarobila's "Walt Whitman and the Panorama" (Walt Whitman Review 25 [June 1979], 51-59), and James Dougherty's Walt Whitman and the Citizen's Eye (Baton Rouge: Louisiana State University Press, 1993) provide closer examination of Whitman's panoramic principles of organization. Fascinating accounts of the ways panoramas have functioned as cultural productions in the history of New York include John Kuowenhoven's classic, The Columbia Historical Portrait of New York: An Essay in Graphic History (New York: Harper and Row, 1953) and John F. Kasson's account of the city as polarized extremes in Rudeness and Civility: Manners in Nineteenth Century Urban America (New York: Hill and Wang, 1990).

4 Emory Holloway and Vernolian Schwarz, eds. I Sit and Look Out: Editorials from the Brooklyn Daily Times by Walt Whitman (New York: Columbia University Press, 1932), 44. All further references will be to this edition and will be documented in the text.

5 M. Wynn Thomas recognizes both Whitman's attachment to and ambivalence about the city in "Walt Whitman and Mannahatta-New York," American Quarterly 34 (1982), 362-378. For accounts of Whitman's responses to the city, especially during his early career in journalism, see Joseph Jay Rubin, The Historic Whitman (University Park: Penn State University Press, 1973), Floyd Stovall, The Foreground of "Leaves of Grass" (Charlottesville: University Press of Virginia, 1974), and Paul Zwieg, The Making of the Poet (New York: Basic Books, 1984).

6 Both the explosion of print journalism and Whitman's immersion in this compelling atmosphere are covered in Shelley Fisher Fishkin's From Fact to Fiction: Fournalism and Imaginative Writing in America (Baltimore: Johns Hopkins University Press, 1985). Another useful source of the particulars of Whitman's journalistic career is Steven H. Jaffe's "The History of the Future: Whitman and the New Journalism" (Seaport [Spring 1992], 26-31).

7 Quoted in "The New Journalists," Page Smith, The Rise of Industrial America (New York: Penguin, 1984), 378.

8 Perhaps Whitman was unaware that one of the city's older parks, Washington Square, was itself constructed on the site of a burial ground, as noted in A Picture of New-York in 1846 (New York: C.S. Francis and Co., 1846), a contemporary guidebook: "Another great and most effective ornament to the city was formed by laying out the ground formerly occupied as Potter's Field. The bones were collected in a vast trench, one on each side of the square, which were enclosed with fences, and planted with trees. For many years this was used for burial purposes, and it is computed that over a hundred thousand bodies have been buried where now assemble for pleasure multitudes of living beings." 
9 The best study of Whitman's urban pastoralism can be found in James L. Machor, Pastoral Cities: Urban Ideals and the Symbolic Landscape of America (Madison: University of Wisconsin Press, 1987). H. Nash Smith's Virgin Land (Cambridge: Harvard University Press, 1950) contains a chapter on Whitman and manifest destiny; more recently, essays by Smith and Leo Marx in Ideology and Classic American Literature, edited by Sacvan Bercovitch and Myra Jehlen (New York: Cambridge University Press, 1986) update theoretical inquiry into perceptions of the land in American literature.

10 Cleveland Rodgers and John Black, eds. The Gathering of the Forces (New York: Putnam's, 1920), 48. All further references will be to this edition and will be documented in the text.

11 Webster's American Dictionary (Boston, 1848), 443.

12 Joseph E. Worcester, Dictionary of the English Language (Philadelphia: Lippincott, 1882), 1669.

13 Emory Holloway, The Uncollected Poetry and Prose of Walt Whitman (New York: Doubleday, 1921), 1:142.

14 Walt Whitman, Complete Poetry and Collected Prose (New York: Library of America, 1982), 431.

15 John Brinckerhoff Jackson, The Necessity for Ruins (Amherst: University of Massachusetts Press, 1980), 125.

16 Charles E. Beveridge and David Schuyler, eds. The Papers of Frederick Law Olmsted, v. 3 (Baltimore: Johns Hopkins University Press, 1983), 11.

17 Clay Lancaster, Prospect Park Handbook (New York: Rawls, 1967), 30.

18 Paul Boyer, Urban Masses and Moral Order in America, 1820-1920 (Cambridge: Harvard University Press, 1978), 247.

19 John Brinckerhoff Jackson, American Space: The Centennial Years, 1865-1876 (New York: Norton, 1972), 217. 